ASPECTS OF A STRATIGRAPHIC SYSTEM: THE DEVONIAN 


\section{Other Macmillan titles of related interest}

D. V. Ager, The Nature of the Stratigraphical Record

J. R. Haynes, Foraminifera

C. S. Hutchison, Economic Deposits and their Tectonic Setting

F. Moseley, The Volcanic Rocks of the Lake District

H. H. Read and Janet Wilson, Introduction to Geology:

Volume 1 Principles

Volume 2, Part 1 Earth History (Early Stages of Earth History)

Volume 2, Part 2 Earth History (Later Stages of Earth History) 


\title{
Aspects of a Stratigraphic System: the Devonian
}

\author{
D. L. DINELEY
}

Department of Geology

University of Bristol

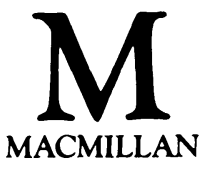


(C) D. L. Dineley 1984

Softcover reprint of the hardcover 1st edition 1984 978-0-333-25640-4

All rights reserved. No part of this publication may be reproduced or transmitted, in any form or by any means, without permission.

Published by

Higher and Further Education Division

MACMILLAN PUBLISHERS LTD

London and Basingstoke

Companies and representatives

throughout the world

ISBN 978-0-333-25641-1 ISBN 978-1-349-17663-2 (eBook)

DOI 10.1007/978-1-349-17663-2 


\section{Contents}

Preface vii

1 INTRODUCTION 1

$\begin{array}{ll}\text { The Devonian System } & 6\end{array}$

$\begin{array}{lr}\text { The Stratigraphic Column } & 7\end{array}$

$\begin{array}{ll}\text { Stratigraphic Procedures } & 12\end{array}$

Breaks in the Succession $\quad 13$

$\begin{array}{ll}\text { Palaeontology } & 16\end{array}$

$\begin{array}{lr}\text { Palaeogeography and Sedimentary Environments } & 18\end{array}$

2 THE MATERIALS OF STRATIGRAPHY 20

Sedimentation Rates and the Stratigraphic Record 22

Devonian Rocks $\quad 24$

$\begin{array}{ll}\text { Sedimentary Facies and Environments } & 27\end{array}$

3 STRATIGRAPHY AND THE WORLD TECTONIC MODEL 30

$\begin{array}{ll}\text { Sedimentation and Subsidence } & 32\end{array}$

Sedimentary Basins $\quad 32$

Cratonic Sedimentary Sequences $\quad 36$

Plate Tectonics and Marine Faunal Diversity 38

An Expanding Earth? $\quad 42$

Oceanic and Atmospheric Repercussions $\quad 43$

4 TIME IN QUESTION: THE DEVONIAN 45

Devonian Marine Facies $\quad 49$

The European Standard $\quad 53$

The Lower Devonian $\quad 55$

The Middle Devonian $\quad 55$

The Upper Devonian $\quad 55$

The U.S.S.R. $\quad 56$

$\begin{array}{ll}\text { China } & 58\end{array}$

Continental Facies $\quad 59$

Radiometric Ages $\quad 61$

5 BIOSTRATIGRAPHY $\quad 63$

Devonian Dramatis Personae $\quad 66$

$\begin{array}{ll}\text { Correlation } & 75\end{array}$ 
$\begin{array}{lr}\text { Biogeographic Provinces } & 83\end{array}$

$\begin{array}{lr}\text { Devonian Faunal Provinces } & 84\end{array}$

6 MANY KINDS OF OLD RED SANDSTONE $\quad 88$

$\begin{array}{ll}\text { General Facies Characteristics } & 90\end{array}$

The Devonian Continental Biota 93

Distribution of Old Red Sandstone Facies $\quad 96$

7 PARALIC AND CRATONIC FACIES 112

$\begin{array}{ll}\text { Shelf Morphology } & 113\end{array}$

$\begin{array}{ll}\text { Paralic Shelf Facies } & 114\end{array}$

$\begin{array}{lr}\text { Devonian Shelf Communities } & 118\end{array}$

$\begin{array}{lr}\text { Cratonic (Epeiric) Deposition } & 118\end{array}$

$\begin{array}{ll}\text { Black Shales } & 121\end{array}$

$\begin{array}{ll}\text { The Spread of Shallow-water Facies } & 124\end{array}$

$\begin{array}{ll}\text { Epicontinental Successions outside North America } & 125\end{array}$

8 WARM WATERS, CARBONATES AND EVAPORITES 136

$\begin{array}{ll}\text { Carbonate Stratigraphy } & 138\end{array}$

$\begin{array}{lr}\text { Devonian Carbonate Buildups } & 142\end{array}$

$\begin{array}{ll}\text { Distribution of Devonian Carbonate Facies } & 144\end{array}$

$\begin{array}{lr}\text { Evaporites } & 149 \\ \text { A Saline Giant } & 150\end{array}$

$\begin{array}{lr}\text { A Saline Giant } & 150\end{array}$

9 DEEP-WATER SUITES 155

$\begin{array}{lr}\text { Deep-water Diagnostics } & 156\end{array}$

Devonian Basins $\quad 159$

$\begin{array}{lr}\text { Central and Western Europe } & 159\end{array}$

$\begin{array}{ll}\text { The Appalachian Basin } & 162\end{array}$

The Cordilleran Geosyncline $\quad 163$

$\begin{array}{ll}\text { The Franklinian Geosyncline } & 164\end{array}$

$\begin{array}{ll}\text { The Ural Geosyncline } & 166\end{array}$

$\begin{array}{ll}\text { The Central Asiatic Complex } & 167\end{array}$

The West Pacific Geosyncline 168

$\begin{array}{ll}\text { The Samfrau Geosyncline } & 168\end{array}$

10 DEVONIAN GEOGRAPHY 174

$\begin{array}{ll}\text { Continents Located } & 175\end{array}$

$\begin{array}{lr}\text { Devonian Orogeny and Continental Collisions } & 180\end{array}$

$\begin{array}{lr}\text { The Oceans and the Epicontinental Seas } & 181\end{array}$

Palaeoclimatic Clues and Discussions $\quad 181$

$\begin{array}{ll}\text { Devonian Days and Years } & 186\end{array}$

$\begin{array}{ll}\text { References } & 190\end{array}$

Author Index $\quad 203$

Fossil Genera and Species Index 206

$\begin{array}{ll}\text { Subject Index } & 210\end{array}$ 


\section{Preface}

The beautiful county of Devon has lent its name to an important and widespread stratigraphic system. The title was proposed by two of the most active and widely experienced geologists in Victorian Britain, men who also influenced numbers of likeminded scientists in Europe, North America and elsewhere. Sedgwick and Murchison would, no doubt, be pleased to see how the sciences of palaeontology and stratigraphy have prospered since 1839 when the term Devonian was given a stratigraphic meaning. They would also perhaps, with their truly Victorian firmly held views and sense of purpose, be eager to debate the relevance of these advances to the newer fields of sedimentological, palaeomagnetic and tectonic studies (and vice versa). They would appreciate the many aspects that a stratigraphic system has and how these change while science advances.

The geological sciences indeed advance rapidly on all fronts and our knowledge of the world as it was in the distant past increases at an ever quickening pace. Much of the new information soon finds its way into lecture courses and textbooks and these tend to follow a pattern that is recognisably conservative and rather predictable. The present volume was prompted not by the wish (or need) to produce an exhaustive or reference treatise on the Devonian system for the scholar or researcher, nor by the desire to produce yet another textbook. It seeks to illustrate the ways in which the different disciplines or interests within geology assist in a general understanding of how things may have been 350 million years ago or thereabouts. It is intended as a book for the interested but not very advanced student of historical geology, and, unintentionally, it no doubt illustrates the difficulties that the writer familiar with one aspect of geology has when he has to try to understand the importance another aspect may have for a theme as big as this one.

A practice among scientists is to prefer the simplest explanation for a collection of facts or events-usually this turns out to be inadequate and more complicated explanations are called for. Thus almost certainly the models of the Devonian world and its inhabitants are naive and even inappropriate. Each of the general subject areas covered in the following chapters makes a contribution to the description and assessment of what took place far back in a specific period of geological time. Each is of importance to one or more of the others and each can be dealt with only briefly here. Some fields of study have been completely neglected in what follows: Devonian volcanism is an example. Others will become apparent.

Comparisons with the state of knowledge and interpretations of other geological systems may be obvious, but the Devonian is nevertheless important in several unique aspects. It was a period of profound, even violem, geological and geographical events 
on the surface of the earth. Plant and animal life responded vigorously. Terrestrial vegetation evolved rapidly to cover more of the land surface than ever before and the vertebrates followed a conquest of both salt and sweet waters by crawling off into the undergrowth. There were also great extinctions and changes in the marine invertebrate world and we are still far from explaining all of these events.

The need for a proper understanding of the way the earth works, and worked then, is paramount and, for the scientifically curious, the 50 million years of the Devonian period are as good as any against which to test new ideas. This account must be brief; it is of necessity incomplete and tentative.

Several points might be nevertheless emphasised here. Palaeomagnetic studies seem to abound in inconsistencies. Those of Devonian rocks are no exception and the accuracies of palaeogeographic reconstructions probably suffer because of possible palaeomagnetic overprinting on the widely distributed Devonian outcrops throughout subsequent geological ages. Palaeomagnetic reversals, similarly, do not seem as yet to offer much help in Devonian correlation. Debate about the extent to which platetectonic theory satisfactorily explains all Palaeozoic palaeogeography still goes on. The pangeic view of the Palaeozoic (as distinct from the 'wandering continent' or kaleidoscopic view) has its ardent adherents and the 'expanding Earthers' are not silenced. In the ensuing pages an essentially orthodox 'steady-state' plate-tectonic view of the earth during Phanerozoic time is maintained. Problems about Devonian faunal and floral distributions remain despite the means of dispersal and isolation being more convincingly depicted in recent publications. The remarkable rise and spread of the vertebrates that are normally regarded as typical of non-marine Old Red Sandstone areas calls for further study. And withal it must be remembered that the Devonian period of some 50 million years lasted almost as long as has the Cainozoic era. The extent of the movements of continents and the extent of changes in the living world in the Devonian were probably not very different from those of the Cainozoic. And both may be called an 'Age of Fishes' though the differences are fairly obvious!

My early contacts with Devonian studies were much encouraged by Dr E. I. White and by the late Professor L. J. Wills. I have since been fortunate in many friends who have helped, by discussion and encouragement, in the writing of this book and I would like to thank them all. In particular my gratitude goes to Professor T. S. Westoll, P. F. Friend, H. G. Reading, E. J. Loeffler, K. C. Allen, B. P. J. Williams, H. H. Tsien, Liu Yuhai, Hou Hong-fei and J. W. Cowie. I would also like to record thanks to members of the I.C.S. Subcommission on the Devonian System who have been so helpful on numerous occasions. Mrs J. D. Rowland turned my manuscript into typescript and Mrs A. Gregory provided the draughting from my sketches-all to my great satisfaction. The blemishes that remain are mine alone.

D.L.D.

Bristol, 1983 